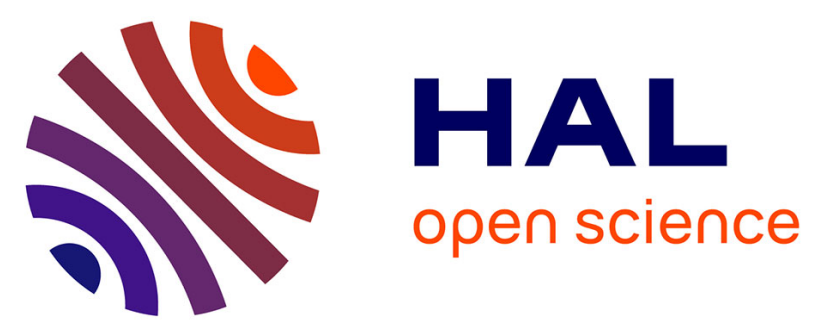

\title{
The Colonial Slave Trade, Slavery and Structural Racial Injustice in France: Using Iris Marion Young's Social Connection Model of Responsibility
}

Magali Bessone

\section{- To cite this version:}

Magali Bessone. The Colonial Slave Trade, Slavery and Structural Racial Injustice in France: Using Iris Marion Young's Social Connection Model of Responsibility. Critical Horizons, 2019, 10.1080/14409917.2019.1596216 . halshs-02437142

\section{HAL Id: halshs-02437142 \\ https://shs.hal.science/halshs-02437142}

Submitted on 13 Jan 2020

HAL is a multi-disciplinary open access archive for the deposit and dissemination of scientific research documents, whether they are published or not. The documents may come from teaching and research institutions in France or abroad, or from public or private research centers.
L'archive ouverte pluridisciplinaire HAL, est destinée au dépôt et à la diffusion de documents scientifiques de niveau recherche, publiés ou non, émanant des établissements d'enseignement et de recherche français ou étrangers, des laboratoires publics ou privés. 
The Colonial Slave Trade, Slavery and Structural Racial Injustice in France: Using Iris Marion Young's Social Connection Model of Responsibility

Magali Bessone

Université Paris 1 Panthéon-Sorbonne

UFR de philosophie

17 rue de la Sorbonne, 75231 Paris Cedex 05

Magali.Bessone@univ-paris1.fr

Abstract: The incorrect conceptualization and evaluation of reparations for the colonial slave trade and slavery, situating demands within the legal, as opposed to the political, domain, has in France resulted in an interpretation of such demands as morally absurd and politically deleterious. Using Iris Marion Young's distinction between a liability model and a social connection model of responsibility, I suggest that the moral claim according to which we (the French population) can today be considered responsible for redressing the structural injustices inherited from the slave trade and slavery is not irrational, nor motivated by a political will to divide the body politic between blamed perpetrators and innocent victims. I begin with an analysis of the difficulties posed by the liability model, focusing on a specific legal case, MIR and CMDP vs. the French state. I then argue that using a political model of responsibility resolves conceptual and normative issues and allows us to understand why, and to what extent, we - contemporary generations - are responsible for redressing the structural racial injustice that continues to endure in French society.

Keywords: Iris Marion Young, social connection model of responsibility, reparations, historic injustices, slavery, France. 
Funding details: This work was supported by the ANR under Grant ANR-15-CE33-0007 for the REPAIRS project.

Biographical note: Magali Bessone is Professor of political philosophy at Paris 1 PanthéonSorbonne University, member of the ISJPS (Institut des Sciences Juridique et Philosophique de la Sorbonne, UMR 8103) and associate researcher at the CIRESC (Centre international de recherche sur les esclavages). Her research focuses on theories of justice, theories of democracy and critical theories of race and racism. She is the author of Sans distinction de race? (Vrin, 2013), the co-editor, with Gideon Calder and Federico Zuolo, of How Groups Matter? Challenges of Toleration in Pluralistic Societies (Routledge, 2014), the co-editor, with Daniel Sabbagh, of Race, racisme, discriminations: une anthologie de textes fondamentaux (Hermann, 2015) and the editor of Méthodes en philosophie politique (PUR, 2018).

Demands for reparations for the colonial slave trade and slavery in France have been consistently repudiated and criticized in public discourses. Two main lines of argument have been used to counter these demands. The first is that the moral grounds upon which the demands are based are deeply counter-intuitive: current generations simply cannot be held responsible for the slave trade and the slavery system of a previous era; they were not born, the French Republic abolished slavery definitively in 1848, and no-one is today advocating the return of slavery. The moral claim that current generations could be held responsible for righting a wrong in which they have played no part is considered to be absurd as it would 
mean that people who were not yet born when the crimes were perpetrated, and who live in a society that has consistently endorsed the moral values attached to the abolition of slavery and the acknowledgment of the heinous nature of the slave trade and slavery in general, can still be held responsible for it. The second line of argument contends that, given the alleged absurdity of the moral claim for reparations, such demands are used to serve another more sinister hidden agenda that is political in nature: they are viewed as contributing to the "memory wars" that have been raging in France in recent decades, ${ }^{1}$ provoking feelings of guilt among whites (the heirs of the slave masters) and fostering resentment among blacks (the descendants of enslaved persons), thus sharpening and rigidifying the divisions between the (perceived) perpetrators and victims instead of eroding potential divisions and contributing to a reconciled body politic.

My aim in this paper is to analyse how this interpretation is produced and radicalized by what I suggest calling a "location problem", i.e. the conceptualization and treatment of reparations for slavery within the legal, as opposed to the political, domain; incorrectly using legal, as opposed to political, categories, norms and procedures to address the issue. I specifically focus on the notion of responsibility that is central to the first line of argument and use Iris Marion Young's distinction between a liability model and a social connection model of responsibility ${ }^{2}$ to suggest that the moral claim according to which current generations can be held responsible for redressing the injustices produced by, and structurally inherited from, the slave trade and slavery is neither irrational nor derived from a maximalist, too-demanding morality, and nor is it motivated by a political will to divide the body politic into blamed perpetrators and innocent victims. The claim that current generations cannot today be legitimately held responsible for redressing deeds perpetrated 150 years ago rests upon a liability model of responsibility used in legal procedures, but its supposed intuitive

\footnotetext{
${ }^{1}$ Blanchard, Veyrat-Masson (eds.), Les Guerres de mémoire.

${ }^{2}$ Young, Responsibility for Justice.
} 
obviousness vanishes if the justification of reparations is based upon a social connection model of responsibility conceived of as a form of political responsibility.

In order to correctly understand the issues involved in reparations for the slave trade and slavery, I will begin by outlining why the liability model of responsibility, paradigmatically used in tort law procedures, is not appropriate. This shall not be done in abstracto: I will present the only legal case that has come to a decision so far in France and anchor my analysis in the arguments used by both the claimants and the judges in the judgment pronounced in Fort-de-France on April 29 ${ }^{\text {th }}, 2014$, in the case MIR Martinique (International Movement for Reparations Martinique), CMDP (World Council of the Pan-African Diaspora) and physical claimants against the French state. The analysis of this case will underline why the backwardlooking, causal, individual and blame-giving character of liability responsibility makes it illsuited to assigning responsibility for reparations in relation to the type of injustices that originated in the slave trade and slavery. However, a closer look at the argument used in court will also show that, while the judges exonerated the state from its liability, they did not absolve the state of responsibility altogether. This evokes the possibility that another model of responsibility might prove more appropriate for making sense of the conceptual and normative problems that arise with cases of historic injustices such as slavery and the slave trade.

The second part of the paper, building upon Iris Young's analysis in "Responsibility and Historic Injustice", ${ }^{3}$ argues that Young's social connection model of responsibility enables the moral grounds for the demands for reparations to be defined and establishes the precise nature of the responsibility that current generations hold for redressing these injustices, which exist as structural "enduring injustices". ${ }^{4}$ In this model, while current generations cannot be held responsible for criminal actions committed in the past (and are neither guilty nor can be

\footnotetext{
${ }^{3}$ Young, Responsibility for Justice, 171-187.

${ }^{4}$ Spinner-Halev, Enduring Injustice.
} 
blamed for them), it establishes that they are responsible for redressing structural injustices whose basis lies in the contemporary reproduction of the racialized system of slavery.

\section{The liability model of responsibility in practice: MIR, CMDP and physical claimants vs.}

\section{the French state}

\section{Uncoupling liability and reparations: the peculiar status of a "declaratory law"}

In 2005, two anti-racist and anti-colonialist associations sued the French state for its responsibility in the colonial slave trade and slavery in Martinique ${ }^{5}$; physical persons joined their claim a few years later. The claimants demanded recognition of the state's responsibility in these historical crimes, the payment of financial compensation to both a Reparations Foundation and to individual claimants, and sought public funding for the creation of a committee of experts dedicated to establishing scientific knowledge related to the crimes and evaluating the current prejudice resulting from them. Their claim was based upon the 2001 so-called "Taubira law", 6 which officially recognized the slave trade and slavery as "crimes against humanity”. The claimants contended that, having obtained this legal recognition, the slave trade and slavery should be recognized as inalienable crimes not subject to statutory limitations. Moreover, they argued that the wording of the law itself suggests that the French state explicitly admits its own responsibility in the execution of the crimes, which, if the prejudice could be established today, would justify the legitimacy of civil reparations. Although the claimants admitted that the idea of reparations is not explicit in the law, they called for an interpretation that directly correlates the notion of liability and the notion of

\footnotetext{
${ }^{5}$ Martinique is a French Caribbean island, formerly a French colony (1635-1946), now a French Overseas Department and Region (DROM).

${ }^{6}$ Law 2001-434, May $21^{\text {st }} 2001$, usually referred to as "loi Taubira", aiming at the recognition of the slave trade and slavery as crimes against humanity. Article 1 of the Law reads: "The French Republic recognizes both the transatlantic and the Indian Ocean Negro slave trade, on the one hand, and slavery itself, on the other, that were practiced from the 15th century, in the Americas, the Caribbean, the Indian Ocean, and Europe against African, Amerindian, Malagasy and Indian populations, as constituting crimes against humanity."
} 
reparation. As a result, they asserted that the Taubira law can be legally regarded as a reparation law.

In their public judgment of April 29, 2014, the judges stated that:

There is no doubt that the state had its share of responsibility in the development of the slave trade and slavery; the Taubira law, although it did not rule explicitly on the liability of the state and/or other actors who made the perpetration of these crimes possible, is an implicit recognition of it; the evidence of this responsibility lies $(\ldots)$ in the objective fact that the colonies were by necessity placed under some form of state authority, hence the state is necessarily responsible for all or part of the facts of the slave trade and slavery; besides, the state does not in addition question the principle of its responsibility, but rather the scope of it. ${ }^{7}$

While the judges therefore admitted the principle of the French state having (some partial) responsibility in the "facts" of the slave trade and slavery, they objected to the interpretation of the Taubira law as a reparation law and emphasized its interpretation as a memory law, i.e. a strictly declaratory law whose object is simply to define a historical fact as a crime, rather than carrying any normative provision per se - such as the provisions attached to the definition of "crime against humanity" in the French Criminal Code. The judges justified their interpretation by resorting to an intentionalist logic, according to which the real meaning of a law in difficult cases can be discovered through, and only through, a careful examination of the intention of the legislator, as attested to by preparatory briefs and internal discussions within the legislative body.

In line with this strict intentionalist method, the judges referred to the debates that surrounded the final formulation and adoption of the Taubira law at the National Assembly. They quoted Elisabeth Guigou's statement (the Minister of Justice) in which she maintained that Article 1 "does not bear any legal consequence, notably in criminal law. However, its

\footnotetext{
${ }^{7}$ Minutes of the Judgment pronounced by the Tribunal de Grande Instance de Fort de France, n ${ }^{\circ}$ R.G. 05/1955, 25 .
} 
symbolic dimension is essential". ${ }^{8}$ They pointed out that the National Assembly had rejected a proposed amendment to Article 1, which had been designed to supplement the first sentence by adding: "[The French Republic] thereby recognizes its responsibility toward the peoples who suffered from these crimes as well as toward the descendants of these peoples. It also commits to determining the harm done and examining the conditions of reparations due for the crimes". The judges concluded by recalling that the wording of Article 4, which states that "a committee of qualified persons" should be created "in order to establish a set of memorials and commemoration events that would guarantee the lasting memory of this crime across the whole of the French territory and over the generations", and that this was chosen in preference to the initial wording, which called for the creation of "a committee of qualified persons whose role is to determine the harm done and examine the conditions of reparations due for the crimes". All these discursive elements can be viewed as strong evidence that the collective deliberation among members of the legislative body converged toward the expression of a single consistent intention (likely to ground the judges' decision beyond any doubt): namely that the notion of "reparation" was unambiguously and deliberately rejected by the legislator in favour of a consensual memorial formulation of the scope of the law. The Taubira law is not normative; it is strictly declaratory. It attaches a legal category, "crime against humanity", to a fact, but it does not correlate any legal repressive dimension with this categorization.

Importantly, if one agrees that in difficult cases the meaning of a law can be entirely derived from the intention of the legislator, as can be inferred from the discussions that ensued within the National Assembly when the law was being adopted, then the judges' interpretation is very likely to be correct: no legal duty of reparation is associated with the recognition of liability in this case. However, several arguments could lead to a different interpretation of this conclusion. Firstly, within an intentionalist theory of juridical

\footnotetext{
${ }^{8}$ Minutes of the Judgment, 26.
} 
interpretation, one could emphasize that what matters is not a "time-slice" analysis of the discussions, exclusively focused on the moment of the law's adoption, but a "genetic" analysis, attentive to the trajectory and evolution of the terms and arguments. In this perspective, the "real" intention behind a law is arguably at least as likely to be found in the initial formulation of the law as in its final, politically negotiated version. Secondly, it is now well-known in theories of deliberative democracy that the publicity constraint produces sideeffects with regard to the relation between "intentions", i.e. the initial preferences of the deliberating partners and the choice of publicly expressed motives in arguing for a decision (motives based on what the partners, embedded in a given public culture, consider more likely to be generally accepted and more useful in order to convince other deliberators). Hence an intentionalist interpretation has to provide a more detailed interpretative method than simple recourse to publicly held discussions within a legislative assembly. Thirdly, the concept of "intention" can refer to at least two things: the meaning of the law, as in the definition of the terms used by the legislator; and the aim of the law, i.e. the social and political objectives that the law was thought to serve in the mind of the legislator. Lastly, the meaning of a law is not necessarily reduced to the normative signification that its author deliberately attached to its formulation: in other words, counter to an intentionalist interpretation, one could argue that what a law really means can be discovered through its jurisprudential uses or its social effects. ${ }^{9}$ In this respect, the judges' interpretation is more revealing of their own legal practice and implicit objectives than of the intrinsic memorial meaning of the Taubira law.

\section{The lack of evidence in the connection between past crimes and present harm}

The judges further considered that "even if the state's liability in the slave trade and slavery were to be admitted, the demands of the claimants would be subject to a statute of

\footnotetext{
${ }^{9}$ In the vast literature about law and its interpretation, see notably Alexander, "All or Nothing at All ?"; Raz, Between Authority and Interpretation.
} 
limitations", regardless of whether the claimants are considered to be the "entitled legal successors of slaves" or persons suffering from "possible personal and current harm". ${ }^{10}$ In other words, the judges rejected the validity of both what the recent philosophical literature has called "the inheritance argument" and "the harm argument". 11

Individual claims from physical persons who provided evidence of genealogical filiation with a slave ancestor (by presenting an emancipation certificate and their own detailed genealogical tree establishing clear descent) were considered admissible. The judges' reasoning was thus based on the usual individualist and causal logic at work in tort law, which is particularly ill-adapted in the case of slavery. Three main problems can be outlined here. Firstly, the logic of tort law implicitly denies that slavery and the slave trade were structural and systemic crimes which had a lasting affect on the social structure of whole population groups or peoples, creating enduring social (and racial) hierarchies, responsibility for the dismantling of which could lie with the state. Hence, claims proceeding from individuals who simply provided a birth certificate attesting that they were born in Martinique were considered non-admissible: there is no collective victim in tort law, and the "Martiniquais people" are no such victim. Secondly, the procedural logic of tort law, based on the existence and evidence of continuous family lines, also disregards the reality of the structures of enslaved families in the French Caribbean: fathers were usually absent from official (legal and religious) sources, rendering family lines or family structures, while not inexistent, invisible and untraceable ${ }^{12}$ :

\footnotetext{
${ }^{10}$ Minutes of the Judgment, 25-26.

${ }^{11}$ Boxill, "A Lockean Argument"; Roberts, "The Counterfactual Conception of Compensation"; Harman, "Harming as Causing Harm"; Shiffrin, "Reparations for U.S. Slavery".

${ }^{12}$ The absence of official matrimonial status and fatherhood does not however exactly mirror what Orlando Patterson calls "natal alienation", i.e. not only "the loss of ties of birth in both ascending and descending generations" but also the "loss of native status, of deracination", which he places at the heart of the slave status in the American context (Orlando Patterson, Slavery and Social Death). This "alienation of the slave from all formal, legally enforceable ties of "blood"" in the French Caribbean, which "instills a doubt about filiation" and makes it difficult for the slave descendants of today to provide legal documentation, should rather be interpreted as having been an empowering manner for enslaved persons to adapt to a violent system of domination and bypass the attempts of masters and priests to discipline slave family lives (Vincent Cousseau, "La famille invisible. Illégitimité des naissances et construction des liens familiaux en Martinique (XVIIe-début du XIXe siècle)").
} 
this amounts to a de facto dismissal of many potentially legitimate claims. Thirdly, from an heuristic point of view, the family line requirement contributes to a shift in the main interpretation of reparations cases away from questions of justice and towards issues of identity politics, as though the underlying question was "what is due to me, considering who I am?" (considering my psycho-physical identity and my specific ancestry) and not "in virtue of which principles could French society be more just? (i.e. are reparatory principles of justice legitimate considering the history of the 'basic structure' of French society or are distributive colour-blind ahistorical principles sufficient for treating all cases of injustice or inequalities?)". The social meaning of the claims for reparations is thus biased: claimants seem to be asking for preferential treatment based on their psycho-physical identities, and not for reasons of equalizing either opportunities or resources. In court, the disruption of family lines does not serve as a legitimate basis for a structural account of the type of injustice initiated by the slave system and not rectified after emancipation: it is strictly viewed in interactional terms ${ }^{13}$ and is used as an argument for delegitimizing individual claims.

In the case of those individuals admitted as legitimate claimants, the judges argued that "neither the harm done to their ancestors", "nor the harm they may still suffer individually or collectively because of this inheritance", were sufficient motives for reparation. According to the inheritance argument, the "heir" status of the descendants of slaves entitles them to claim for possessions that their ancestors were unjustly denied. Specifically, the descendants of slaves are entitled to claim for the reparations that should have been granted their ancestors when they acquired the legal status of "persons" following the abolition of slavery; rights and properties that they were previously denied and were never subsequently granted. According to this argument, the heirs are entitled to receive the patrimonial debt owed to their ancestors and passed down over the generations. The judges in the case, however, raised one main

\footnotetext{
${ }^{13}$ On the distinction between interactional and structural injustices, see Catherine Lu, Justice and Reconciliation in World Politics.
} 
objection to this argument: the legal norm adopted in the abolition decree never sanctioned any entitlement to reparations or compensation ${ }^{14}$ for the former victims of slavery: the state may have incurred a moral debt, but there is no legal basis for a claim for reparations that would aim to rectify the prejudice associated with the fact that formerly enslaved persons passed from the legal status of "goods" (their status as defined in the articles of the Black Code, incorporated into the French Civil Code after 1803) to the legal status of "persons". It may now be tempting to say that given the current status of the legal norms, the decree was wrong and constituted a great injustice; but the limitation period for debt recovery (four years when the debtor is the state) has expired: the action of the plaintiffs is legally subject to limitation by lapse of time and is therefore no longer valid.

The judges also dismissed the harm argument, although they acknowledged that the action of the plaintiffs might not be time-barred in this case. Bernard Boxill summarizes the argument as follows in the case of African Americans:

Slavery involved many transgressions against the slaves. The slaves were harmed by these transgressions. These harms initiated an unbroken chain of harms linked as cause and effect that persists to the present day. Since present day African Americans therefore suffer from harms caused by the transgressions of slavery, it follows from the principles of reparative justice that they deserve reparation for those harms. ${ }^{15}$

In this argument, the plaintiffs must prove that they are today suffering the effects of the initial harm committed against the enslaved persons, effects which produced a continuous series of causally linked events or states of affairs that directly affect them today. The lack of opportunities or resources that the claimants suffer from today would probably still exist even if the initial harm had not affected their ancestors and constituted an obstacle to their life prospects. This interpretation rests upon a counterfactual notion of harm, that, to put it very

\footnotetext{
${ }^{14}$ On the contrary, some compensation was granted to the former owners by article 5 of the Abolition Decree, April 27, 1848, for the loss of their properties.

${ }^{15}$ Bernard Boxill, "Black Reparations".
} 
simply, enables the comparison of the actual situation $t 1$ to a hypothetical situation $t$ ' 1 , conceived as the result of a causal chain from a hypothetically ideal initial situation $t^{\prime}$ in which the harm done at $t$ would not have been committed.

The judges raised two main objections to this argument: one about the indeterminacy of the effects of the harm; the other about the difficulty of identifying the rights that were violated by the harm. Firstly, it is difficult to evaluate how the victims would have fared had the injustice not been committed against them; and this difficulty only increases with time. Given the passage of time, the robustness of a causal link between the initial harm committed against the slaves and the current harm suffered by their descendants is impossible to establish with sufficient certainty - any appraisal would necessarily fail to "characterize it in a certain and individual way". ${ }^{16}$ In other words, it is impossible to determine with sufficient certainty that the initial harm is causally responsible for the current harm. The judges adopted here a version of the indeterminacy thesis famously defended by Jeremy Waldron, ${ }^{17}$ according to which, despite some indications provided by probabilistic reasoning and general knowledge about human psychology, it remains impossible to determine, after several generations, what would have become of the descendants if the harm had not initially been committed against their ancestors or if it had been redressed. Hence, even if one can establish that today's claimants are indeed in a disadvantaged position compared to other members of the French population, it is impossible to determine whether, and to what degree, their disadvantage can be traced to the crime of slavery suffered by their ancestors, to the political marginalization and economic exploitation that occurred after emancipation, or to other personal decisions made by the claimants themselves. In Daniel Butt's terms, "identifying the morally relevant counterfactual" 18 proves particularly tricky when dealing with historic injustices. The required

\footnotetext{
${ }^{16}$ Minutes of the judgment, 26.

17 Jeremy Waldron, "Superseding Historic Injustice" and "Redressing Historic Injustice".

${ }^{18}$ Daniel Butt, Rectifying International Injustice, 102.
} 
continuity of the causal relation of harm is impossible to retrace retrospectively. The effects of slavery are barred by limitation.

Secondly, in civil law, the harm is not only the causal consequence of a prejudice, but is also based on a juridical condition that establishes that the prejudice indeed consisted in the transgression of a legal norm. Thus, in order to establish the legal reality of the "harm" of slavery, it must either be established that slavery violated a right at the time when the prejudice was committed (which is obviously impossible, given the complicity of the French legal system in the perpetration of slavery before 1848), or that today's law retroactively states that it was an imprescriptible crime - an assertion that is dismissed by the interpretation of the Taubira law as only declaratory and without any normative weight. Therefore, the moral harm (the "crime against humanity") cannot strictly speaking be constituted as a legal harm - as giving an entitlement right to compensation. So even those individual claimants that are declared legitimate claimants cannot receive reparations because the harm cannot be established.

\section{Denying the court's responsibility in establishing the political responsibility of the State}

The judges applied a different logic to the claim originating from the two anti-racist and anti-colonialist associations. They interpreted it as "related to a duty of memory", and distinguished two sub-claims within this: "symbolic recognition" and "scientific knowledge". ${ }^{19}$ This memorial interpretation is congruent with the republican French public philosophy that conflates reparatory claims, historical narratives and memory struggles and insists that the latter are critical to the construction or destruction of the national collective identity, which is the only legitimate collective identity ${ }^{20}$. This congruence, as has been amply demonstrated in the field of critical legal studies, is simply evidence that judges' categories of

\footnotetext{
${ }^{19}$ Minutes of the judgment, 24.

${ }^{20}$ Sophie Guérard de Latour, "La France perd-elle la mémoire ?”; Cécile Laborde, "The Culture(s) of the Republic". On the notion of "French public philosophy", see Cécile Laborde, Critical Republicanism.
} 
analysis and decisions are never strict applications of legal procedures and legislations, but are always profoundly shaped by the mainstream principles and values of the society of which they are a part. Legal arguments do not exist in an ideal vacuum. And such shaping is a reciprocal process: in turn, judiciary decisions contribute to informing ordinary moral and political categories and arguments. The whole process forms what John Rawls calls the "public political culture" of a society. ${ }^{21}$

Reducing the reparations claims of the associations to a "duty of memory" had two important consequences in the judges' reasoning: first, "symbolic recognition" and "scientific knowledge" refer to Articles 4 and 2 respectively of the Taubira law: the creation of a committee of qualified persons to establish memorials and commemoration events (Art. 4) and the requirement that research programmes (through national calls for projects) and school curricula in history and the social sciences should examine the slave trade and the significance of slavery (Art. 2). So both potential claims for reparations were, in the judges' opinion, already covered by law. Second, after declaring that the associations' claims were, for that reason, political aims, the judges concluded: "it is not the place of judicial power to substitute the state in determining the conditions of implementation of some policy, even if such policy is required by law". ${ }^{22}$ Hence, the "duty of memory", in the form of implementation of educational and cultural programmes, falls outside of the legitimate scope of the judiciary. French judges can therefore dismiss the charges against the state on the grounds that the responsibility of the state is a political, but not a legal matter, and that it is not the "role responsibility" of the judiciary to take on such political functions. The judges can simultaneously acknowledge that the French state is responsible for slavery - i.e. they can assert a moral fact about the state - and that the judicial system is not entitled to hold it

\footnotetext{
${ }^{21}$ Rawls, Political Liberalism, 13-14: the public political culture of a society "comprises the political institutions of a constitutional regime and the public traditions of their interpretation (including those of the judiciary), as well as historic texts and documents that are common knowledge".

${ }^{22}$ Minutes of the judgment, 24.
} 
responsible - i.e. they can't expect the state to perform various social and political actions in order to appropriately answer for the slave trade and slavery.

To sum up this section, a closer examination of the judges' arguments in this specific civil case supports Iris Marion Young's claim that “[c]ases of historic injustice whose original perpetrators and victims lived generations ago present particular ontological and conceptual problems when we try to apply the liability model to them". ${ }^{23}$ The liability model of responsibility, used in tort-law procedures, is ill-adapted to conceptualize and evaluate the type of responsibility at stake in repairing historic injustices. The conclusion that the French state can be considered both responsible and not liable for the slave trade and slavery is the result of the "location problem" at the heart of reparations claims: the meaning of "responsibility" becomes conceptually opaque and normatively empty when it is used in causal, individual, backward-looking proceedings. By contrast, I want to suggest in the next section that defining the type of responsibility involved in facing up to historic structural injustices as political responsibility, following Young's social connection model, clarifies the notion of responsibility from a conceptual perspective and points at some of the political obligations such responsibility implies in a normative perspective.

\section{A social connection model of responsibility for the slave trade and slavery}

Iris Young outlines four key features that distinguish the social connection model of responsibility from the liability model of responsibility: the social connection model does not single out perpetrators who would be the focus of blame and sanction while others are absolved; it does not conceive of an instance of harm as a specific deviation from an acceptable baseline or set of background conditions, but questions and evaluates the background conditions themselves; it is forward-looking rather than backward-looking: it

\footnotetext{
${ }^{23}$ Young, Responsibility for Justice, 174.
} 
incites agents to act so as to transform the processes and institutions that produced injustices and enjoins them to aim at specific desirable outcomes; lastly, under the social connection model, responsibility is "essentially shared": it is personal and discharged only through collective action. $^{24}$

Young designed the social connection model of responsibility in order to provide insight into the responsibility of current generations to address structural injustices. The first question that needs to be addressed in order to evaluate the applicability and relevance of the social connection model to historic injustices is whether, and in which specific sense, the latter are structural and in what regard they therefore require the theorizing of "a more active relation between individuals, socio-structural processes, and responsibility". ${ }^{25}$ Once this is established, the actual nature of political responsibility will also have to be specified, notably regarding the relation it poses between the state and "us" - where "us" is understood to mean the current French population. This will allow an understanding of how holding the state responsible cannot be reduced to blaming the state and absolving the citizens.

\section{The slave trade and slavery as structural injustices}

In her foreword to Responsibility for Justice, Martha Nussbaum states that she doesn't see how the content of chapter seven, entitled "Responsibility and Historic Injustice", is logically connected to the argument developed through the rest of the book:

A separate paper on Fanon on historic injustice, which discusses the question of reparations for slavery, remains less clearly placed in the project as a whole. It discusses similar questions in a similar way, but it does not contribute a missing piece to the argument, thus it functions as an appendix rather than as a chapter. ${ }^{26}$

\footnotetext{
${ }^{24}$ Young, Responsibility for Justice, 104-113.

${ }^{25}$ Ibid., 40.

${ }^{26}$ Ibid., xi.
} 
Young provides an overview of the book as a whole in the first chapter "From personal to political responsibility", presenting her argument that in order to understand how individual moral agents should think about their relationship to the socio-structural processes that produce injustices, and about their responsibility to change those processes, "a conception of responsibility that does not assume blame, fault, or liability as the primary way of assigning responsibility"27 needs to be developed. The liability conception discharges individual moral agents from thinking about their relations to structural injustices, instead inciting them to identify guilty moral agents (who may be individual or collective agents) and to consider that, if structural conditions need to be changed, the obligation to do so falls exclusively to the guilty parties. By contrast, the social connection conception of responsibility, which Young develops in chapters 2 to 5 , insists that individual moral agents should feel personally concerned with understanding their own relation to structural injustices and changing the socio-structural conditions that produce such injustices.

Chapters six and seven, which are not mentioned in chapter one, are both to be interpreted, in my opinion, as an important "non-ideal" aspect of the theory of the social connection model of responsibility. Here, "non-ideal" doesn't only refer to the "subject matter" of the theory: a non-ideal theory is a theoretical activity in which philosophers engage when they examine the normative appropriate responses to departures from the ideal situation and they are concerned with the rectification of identified injustices. In this sense, Young's whole approach is obviously a non-ideal approach since it examines what should be required of us, as moral agents, in response to certain forms of existing structural injustices. However, chapters 6 and 7 are instances of another aspect of a non-ideal theory, which Daniel Butt identifies as a concern for a "double practicality”, “... in that it aims to develop arguments which can realistically be employed by the protagonists in this real world debate". ${ }^{28}$ In other

\footnotetext{
${ }^{27}$ Ibid., 40.

${ }^{28}$ Butt, Rectifying International Injustice, 8.
} 
words, in these chapters, Young is concerned with convincing real moral agents (us) that the foundational premises of her argument are congruent with our moral intuitions. Chapters 6 and 7 thus articulate and respond to possible denials of responsibility from individual moral agents - after the theory has been positively, and theoretically, exposed and developed. From this perspective, both chapters take people's voiced resistance to acknowledging any personal involvement with structural injustices seriously. Chapter six, entitled "Avoiding Responsibility", considers four strategies that individual moral agents typically use in order to deny that they have any responsibility for structural injustices: reification, denial of connection, demands of immediacy, and claims that it is "not my job" to correct injustices. Following on from this, chapter seven then considers a very powerful and even more complicated real-world situation of denial - the case of historic injustices - in which all objections seem even more potent, notably because of the passing of time. Chapter seven, far from being an "appendix" as Nussbaum suggests, is therefore paradigmatic of the argumentative strategy that individual moral agents may use in order to avoid responsibility for structural injustices, and hence is also paradigmatic of the argumentative strategy that should be deployed in response in order to overcome moral agents' resistance to organizing collective action to correct structural injustices. Historic injustices, and our political and moral relation to them, provide the best empirical test for the normative validity of the social connection model of responsibility: if we are able to understand that we are responsible for redressing historic injustices (although not guilty of those historic injustices) because and when they are structural injustices, we will be able to take action to rectify them.

This hypothesis supposes that (some) historic injustices are correctly viewed as significant instances of structural injustices - that they are not of a different nature - "wrongs traceable to specific individual actions or policies", ${ }^{29}$ and that they don't simply add up to existing

\footnotetext{
${ }^{29}$ Young, Responsibility for Justice, 44.
} 
structural injustices, for which we would be responsible regardless of their historic nature. Mick Malpas, in his review of the book Responsibility for Justice, argues that this point is lacking in Young's exposition. He writes:

Although Young claims that historic injustice affects our social responsibility to others, it is hard to see how historic wrongs could give rise to any responsibilities (...) over and above those responsibilities demanded by straightforward social justice, and Young does not provide an account of why it would be otherwise. The fact that a structural injustice is a result of a historic wrong should not make any difference (either in quality or degree) to our responsibility to remedy that injustice. (...) By Young's own account, our responsibility to redress social injustice seems to depend just on our present social connection to some structural injustice and should not be 'backward-looking'.

There are three different elements to consider in response to Malpas' assertion. Firstly, Young doesn't need to prove that historic injustices give rise to different ("either in quality or degree") or preponderant ("over and above") responsibilities for remedying social injustices. Rather, all she needs to show is that the historic nature of some socio-structural injustices does not annul our responsibility toward them, and that indeed, we have the same responsibility to address them as non-historical structural injustices. Her aim is to reply to a possible denial of responsibility when socio-structural injustices are viewed as "the result of a historic wrong", a denial that would, for instance, be expressed along the following lines in Richard Epstein's words:

We do not face slavery or segregation. There is no support anywhere in this nation for a return to either practice. The effort to place reparations front and center ignores that time has shifted the locus of our current concerns to a new set of issues that will not be resolved by reliving the horrors of an early generation in some collective or official capacity. We have to live life going forward. We cannot make collective amends for all the wrong in the past. But we can create new and unnecessary hurts by trying to remedy past wrongs. A divisive campaign for

\footnotetext{
${ }^{30}$ Malpas, "Review Responsibility for Justice", e8.
} 
reparations will undercut the efforts that we all want to make a stronger, more vital, more productive and more caring nation. ${ }^{31}$

Young's social connection model of responsibility constitutes a specific response to the arguments according to which 1) we (current generations) can't be blamed for slavery because the practice has disappeared and is not concomitant with contemporary moral values; 2) slavery was wrong, but it belongs to the past and we are not the perpetrators of the horrors it engendered; 3) we are responsible for producing a "more caring nation" in the future, but we are not guilty of past crimes. Young's model does not ask for "collective amends for all the wrong in the past": the strength of her argument is that while it grants that we are not guilty or blameable for slavery, it asks us to acknowledge the structural continuity of such injustices and our responsibility for redressing them. The slave trade and slavery are historic sources of contemporary structural injustices, which contemporary agents are responsible for remedying due to the continuity of the social structures in which contemporary moral agents participate $^{32}$.

Secondly, and most importantly, Malpas' objection and Epstein's denial rest upon a misunderstanding of the nature of historic injustices - at least, those we are interested in here. Historic injustices are socio-structural injustices, not because some "past wrong" with identifiable perpetrators causally resulted in an injustice today against identifiable victims, but because the slave trade and slavery led to the establishment of "enduring" racial norms, institutions, discourses, material conditions and social hierarchies that are still shaping contemporary social structures and continue to be reproduced in present-day social conduct. Young's understanding of historic injustices is on a par with Spinner-Halev's "theory of historical injustice":

\footnotetext{
${ }^{31}$ Epstein, "The Case Against Black Reparations", 1192.

${ }^{32} \mathrm{On}$ the precise relation between historic injustice and structural injustice, see Catherine Lu, Justice and Reconciliation in World Politics (esp. Chap. 5) whose account also builds on Iris Young's work.
} 
$[\mathrm{T}]$ he critics of working to repair past injustices might ask, why does the history of an injustice matter? Injustices today ought to be addressed, they argue, but why does the pedigree of the injustice matter? The critics are right in a narrow sense, that current injustice matters more than past injustice, but they are wrong to treat long-standing injustices in the same way as other injustices. (...) Enduring injustice has roots in the past, and continues into the present day; an enduring injustice endures over time and often over space as well. ${ }^{33}$

The reason we have a responsibility to repair historic injustices, when we are responsible for them, is that for some groups, their past and present experience is a continued experience of injustice, "and the future appears to be unjust for them as well, without some change in course of action". ${ }^{34}$ This is also the reason why we are not responsible "for all the wrong in the past", but for these present injustices that can be traced backward and projected forward, and which, for this reason, call for specific political and moral attention ${ }^{35}$. The slave trade and slavery produced such enduring structural injustices: not only were they themselves systems of social, economic, political and legal practices in which the guilty perpetrators cannot easily be discerned from other agents, ${ }^{36}$ but these systems are also at the root of current norms and practices that cannot be traced to isolated actions or policies, but rather have arisen from the "normal, ongoing structural processes of the society"37. These processes are inherited from the racial divide that the colonial slave trade and slavery established and which, after abolition, far from becoming blurred, became rigidified and was rigorously maintained; the

\footnotetext{
${ }^{33}$ Spinner-Halev, Enduring Injustice, 56.

${ }^{34}$ Ibid.

${ }^{35} \mathrm{C}$. Lu is right to question Spinner-Halev's exclusive focus on cultural groups, and exclusion of gender- and class-based injustices from this type of enduring injustices we should focus on in our efforts towards reparation. But I tend to think that, as Lu herself suggests, nothing in his account explicitly bars a wider interpretation, according to which "the concept of enduring injustice can encompass other kinds of structural injustices" (Lu, Justice and Reconciliation in World Politics, 161).

${ }^{36} \mathrm{Lu}$, "Colonialism as Structural Injustice", 269.

${ }^{37}$ Young, Responsibility for Justice, 181.
} 
structural racial divide was neither questioned nor corrected. The racial patterns of privilege and disadvantage that the slave system enacted continue to be reproduced today. ${ }^{38}$

The nature of these historic injustices is, thirdly, the reason why considering the past processes that contributed to producing structural injustices today helps us understand the specific nature of our responsibility. This is not "backward-looking": acknowledging our historical condition allows us to identify the type of responsibility we bear for the future. Identifying the slave trade and slavery as a major source of enduring injustices that are both structural and racial enables a broader understanding of the fact that the racial identity ${ }^{39}$ of people occupying different positions in the social order today is significant for choosing the appropriate policy for remediating unjust inequalities. We can't simply be satisfied with colour-blind policies which pretend that our social connections to injustices are of a strictly economic individualistic nature, regardless of our racial affiliations. ${ }^{40}$ Our social connections and the different positions people occupy in society have been continuously shaped by racial injustices: taking their history into account is fundamental to formulating the specific requirements of our forward-looking responsibility. In Young's terms, "an account of the continuities of present with past injustices is important for understanding how the present conditions are structural, how these structures have evolved, and where intervention to change them may be most effective." ${ }^{41}$ It may help us to identify racial injustice as a particularly pressing type of structural injustice, because of its enduring nature, and to create policies that attempt to overcome social inequalities by targeting individuals or groups. Measures that confront the racial divide can be identified as more effective to transform the profound

\footnotetext{
${ }^{38}$ For a historical and anthropological analysis of this rigidifying process in the French Carribean, see Bonniol, La Couleur comme maléfice. For important sociological diagnostics and accounts of racialized forms of injustice in contemporary France, see Chapman and Frader (eds.), Race in France; Fassin and Fassin (eds.), De la question sociale à la question raciale; NDiaye, La Condition noire.

${ }^{39}$ Needless to say, this racial "identity" does not refer to any given, natural, substantial identity, but to various modes of self-identification and external ascription that are historically constructed and contextually situated.

${ }^{40}$ On the "sociological naivety" and superficiality of this "moral standard" of colour-blindness, see Loury, "Trans-generational justice".

${ }^{41}$ Young, Responsibility for Justice, 182.
} 
injustices of our society than measures that remain oblivious of the ascribed racial membership of disadvantaged groups.

\section{Our political responsibility to repair structural racial injustice}

Malpas and Epstein, when raising doubts about the legitimacy of contemporary responsibility for repairing historic injustices, also voice a concern directly connected to my last point: focusing on current injustices whose roots lie in slavery "over and above" "new sets of issues" may be counter-productive and divisive - not only symbolically divisive of the nation, but also, much more pragmatically, divisive in terms of the limited material resources the state can use in order to redress current injustices. However, in this case again, Malpas' and Epstein's critical stance rests upon a misunderstanding concerning the type of expectations we can derive from our political responsibility toward enduring injustices. Political responsibility does not belong to a zero-sum game type of distribution of goods, according to which being responsible for a specific set of actions that aims to transform the structural processes and institutions that produced wrongs would, by definition, lower our responsibility for other sets of actions. Contemporary responsibility for historic structural injustices is political, which, I suggest, should be understood in Nancy Fraser's terms, as belonging to the political dimension of justice, not the distribution (nor the recognition) dimension. $^{42}$

Fraser recently revised her previously bi-dimensional model of justice, which identified two distinct species of injustice, maldistribution and misrecognition, by introducing a political dimension. In this new framework, the latter is both a third sphere, situated at the same analytical level, so to speak, as the economic and cultural spheres, and the dimension that provides an encompassing norm of justice, that of "parity of participation", which provides a

\footnotetext{
${ }^{42}$ Fraser, Scales of Justice.
} 
grounding for all three paradigms (in which case the political sphere includes the economic and cultural spheres). Fraser specifies the meaning and status of "political" as follows:

Of course, distribution and recognition are themselves political in the sense of being contested and power-laden; and they have usually been seen as requiring adjudication by the state. But I mean political in a more specific, constitutive sense, which concerns the scope of the state's jurisdiction and the decision rules by which it structures contestation. (...) Centered on issues of membership and procedure, the political dimension of justice is concerned chiefly with representation. ${ }^{43}$

In her renewed analysis, "overcoming injustice means dismantling institutionalized obstacles that prevent some people from participating on a par with others, as full partners in social interaction". ${ }^{44}$ I want to suggest that our political responsibility for redressing structural racial injustices consists in transforming social processes and political institutions so that all members of a society can "participate on a par with others" in the discussion about the norms that regulate society and define its membership requirements. This political responsibility is particularly pressing because many racialized members of our society have been consistently deprived of this participation.

Understanding political responsibility using the paradigm put forth by Fraser allows us to comprehend why it is shared and not collective - i.e. why we, as citizens, are directly and personally responsible for transforming the institutions that have permitted and maintained racial injustices, and for making them into a structure under which such injustices are rectified and prevented from recurring. We have an individual responsibility to hold states and their representatives accountable for their actions and decisions, which are our actions and decisions, authorized by the representation mechanism that historically ascribed who is included in, and who is excluded from, the French people. This responsibility extends to resisting a routine use of institutional processes when they are identified as facilitating

\footnotetext{
${ }^{43}$ Ibid., 17.

${ }^{44}$ Ibid., 16.
} 
injustices, i.e. as excluding some members of society from being full partners in social interactions.

Viewed from this perspective, although the judiciary is admittedly not the right location for assigning responsibility for reparations, the decision of the two anti-racist and anti-colonialist associations and the physical persons to go to court and confront the French state for its responsibility in the slave trade and slavery can be seen as contributing to an effective form of "strategic legalism"45. Their intention may not have been to try to blame or sanction the state, but to find, in the courthouse, an echo chamber able to give visibility to and publicize one of the institutional obstacles to the equal participation of all members of society in discussions about membership, the lack of "symbolic recognition", and "scientific knowledge" about the enduring racial injustice inherent in the structure of French society. The legal action may have served to unveil how the French legal system is largely devoid of the capacity to produce political justice when historic racial injustices are at stake. In order for such cases to play their part in developing a shared conversation about how to transform social institutions, the norms, categories and arguments of the court's decisions should be made widely visible and accessible, and feed that conversation. Unfortunately, in France, court decisions are often simply not widely, publicly accessible, and often don't explicitly state the norms, values, or even the procedures on which they are based.

Lastly, understanding our political responsibility for structural injustices as normatively grounded on the norm of parity of participation allows us to understand why, according to Young, its main requirement lies with "dealing with it as memory". ${ }^{46}$ Regardless of our specific positions of power, privilege, interest, and collective ability (the four parameters that Young identifies as factors qualifying our differentiated forward-looking responsibility for changing structural processes), each of us should be part of a collective conversation about

\footnotetext{
${ }^{45}$ The term has been coined by Peter Maguire, Law and War; I use it here in a loose way, analogous to Gayatri Spivak's "strategic essentialism".

${ }^{46}$ Young, Responsibility for Justice, 182.
} 
our past, and ensure that all members of French society are on a par with one another in the formulation of our shared narrative.

We are responsible in the present for how we narrate the past. How individuals and groups in the society decide to tell the story of past injustice and its connection to or break with the present says much about how members of the society relate to one another now and whether and how they can fashion a more just future. (...) A society aiming to transform present structures of injustice requires a reconstitution of its historical imaginary, and the process of such reconstitution involves political contest, debate, and the acknowledgment of diverse perspectives on the stories and the stakes. ${ }^{47}$

Our current political responsibility for redressing enduring injustices such as the structural racial divide established by the colonial slave trade and slavery, lies with giving a voice to all those concerned with transforming the conditions of membership, which are themselves deeply entrenched in past institutionalized exclusion. We are not guilty of France's criminal past, but we are responsible for knowing our history and the socio-historical reality of continuous structural injustices inherited from our past and constantly perpetuated in our norms and practices; and we are responsible for changing it.

${ }^{47}$ Ibid. 


\section{Bibliographical Elements.}

Alexander, Larry. "All or Nothing at All? The Intentions of Authorities and the Authority of Intentions". In Law and Interpretation, edited by A. Marmor. Oxford: Clarendon Press, 1995. Blanchard, Pascal and Isabelle Veyrat-Masson, eds. Les Guerres de mémoire. La France et son histoire. Paris: La Découverte, 2008.

Bonniol, Jean-Luc. La Couleur comme maléfice. Une illustration créole de la généalogie des Blancs et des Noirs. Paris: Albin Michel, 1992.

Boxill, Bernard. "Black Reparations". In The Stanford Encyclopedia of Philosophy (Spring 2011 Edition), edited by Edward N. Zalta.

http://plato.stanford.edu/archives/spr2011/entries/black-reparations/.

Boxill, Bernard. “A Lockean Argument for Black Reparations”. Journal of Ethics 7 (2003): 63-91.

Butt, Daniel. Rectifying International Injustice. Principles of Compensation and Restitution between Nations. Oxford: Oxford University Press, 2009.

Chapman, Herrick and Frader, Laura L. (eds.). Race in France. Interdisciplinary Perspectives on the Politics of Difference. New York: Berghahn Books, 2004.

Cousseau, Vincent. “La famille invisible. Illégitimité des naissances et construction des liens familiaux en Martinique (XVIIe-début du XIXe siècle)". Annales de démographie historique, special issue "Familles en situation coloniale", 2011/2, n¹22: 41-67.

Epstein, Richard A. “The Case Against Black Reparations”. Boston University Law Review 84 (2004): 1177-1192.

Fassin, Didier and Fassin, Eric (eds.). De la question sociale à la question raciale? Représenter la société française. Paris: La Découverte, 2006.

Fraser, Nancy. Scales of Justice. Reimagining Political Space in a Globalizing World. New York: Columbia University Press, 2009. 
Guérard de Latour, Sophie. "La France perd-elle la mémoire ? Pour une défense républicaine des luttes mémorielles". In Histoire et subjectivation, edited by A. Giovannoni, J. Guilhaumou. Paris: Kimé, 2008.

Harman, Elizabeth. "Harming as Causing Harm”. In Harming Future People, edited by Melinda A. Roberts and David T. Wasserman, 137-154. New York: Springer, 2009.

Laborde, Cécile. Critical Republicanism. Oxford: Oxford University Press, 2008.

Laborde, Cécile. "The Culture(s) of the Republic. Nationalism and Multiculturalism in French Republican Thought”. Political Theory 29, No 5 (2001): 716-735.

Loury, Glenn. “Trans-generational Justice: Compensatory versus Interpretative Approaches”. In Reparations: Interdisciplinary Inquiries, edited by Jon Miller and Rahul Kumar, 87-113. New York: Oxford University Press, 2007.

$\mathrm{Lu}$, Catherine. "Colonialism as Structural Injustice: Historical Responsibility and Contemporary Redress”. Journal of Political Philosophy 19(3) (2011): 261-281.

Lu, Catherine. Justice and Reconciliation in World Politics. Cambridge: Cambridge University Press, 2017.

Maguire, Peter. Law and War. New York: Columbia University Press, 2001.

Malpas, Mick. "Review Responsibility for Justice". Contemporary Political Theory 12(4) (2013): e5-e9.

NDiaye, Pap. La condition noire. Essai sur une minorité française. Paris: Calmann-Lévy, 2008.

Patterson, Orlando. Slavery and Social Death. Cambridge: Harvard University Press, 1982.

Rawls, John. Political Liberalism. New York: Columbia University Press, 1993.

Raz, Joseph. Between Authority and Interpretation. Oxford: Oxford University Press, 2009.

Roberts, Rodney C. "The Counterfactual Conception of Compensation". Metaphilosophy 37 (2006): 414-28. 
Shiffrin, Seana Valentine. "Reparations for U.S. Slavery and Justice Over Time". In Harming Future People, edited by Melinda A. Roberts and David T. Wasserman, 333-339. New York: Springer, 2009.

Spinner-Halev, Jeff. Enduring Injustice. Cambridge: Cambridge University Press, 2012.

Waldron, Jeremy. "Redressing Historic Injustice". University of Toronto Law Review 52 (2002): 135-160.

Waldron, Jeremy. "Superseding Historic Injustice”. Ethics 103 (1992): 4-28.

Young, Iris Marion. Responsibility for Justice. Oxford: Oxford University Press, 2011. 